\title{
Effective Implementation of Rehabilitation Therapy for In-Patients of Federal Psychiatric Hospital, Calabar
}

\author{
Article by Umoh, Edet Okon \\ Nursing, Texila American University, Nigeria \\ Email:- edetokonu@ymail.com
}

\begin{abstract}
The study was carried out to examine effective implementation of rehabilitation therapy for in-patients of Federal Psychiatric Hospital, Calabar, Cross River State of Nigeria. Four objectives and four research questions were formulated to guide the study. Ex-post facto research design was used for the study. The population of study comprised of 150 in-patients in Federal Psychiatric Hospital, Calabar, Cross River State, Nigeria. Simple random sampling technique was used to select 50 stable in-mates for this study. An instrument titled "Effectiveness of Implementation of Rehabilitation Therapy for in-patients of Federal Psychiatric Hospital Calabar", was used for data collection. Simple percentages, mean, standard deviation and r-value of Pearson Product Moment Correlation were used for answering the research questions, the result of the study revealed that there are few rehabilitation programmes available for the patients. The result also revealed that the patients have positive attitude towards the rehabilitation programmes. The result further revealed that parent's level of involvement in the rehabilitation programme is low. And lastly, the result revealed that there is a relationship between instructors' qualification and effective implementation of the rehabilitation therapy. Based on the findings, it was concluded that rehabilitation programmes are effectively implemented in the Federal Psychiatric Hospital Calabar, Nigeria. It was recommended among other things that more rehabilitation programmes should be introduced into the hospital, this will help to meet the needs of the various patients.
\end{abstract}

Keywords: Rehabilitation, Psychiatry, Institutionalization, Effectiveness, Psychosomatic, Implementation, Preponderant

\section{Introduction}

Psychiatry illness was believed to be an irreversible disorder where sufferers are never expected to be useful or productive to self and society. Obviously most psychiatric patients are dependents, irresponsible, unproductive and problematic to environments. Most families exclude them from others and when sharing rights; theirs may be allotted to a third party who may, or may not deliver to them. This is not peculiar in all psychiatric cases especially where the dysfunction does not cause a permanent brain damage and the psycho-somatic apparatus are active and intact. The concept of Rehabilitation is a way of helping an inflicted, injured or ill patient to resume self activity, regain independence and mobility. It is a recovery approach to guide someone attains self effort. Ikpeme, E. (2015) declares that the hospital rehabilitation is very useful to every patients referred to the centre, even to out patients from out side visiting to acquire vocational/skill acquisition and job placement.

Psychiatric disorder is of varying degree depending on age of onset and cerebral involvement. Mental illness occurring at adolescence when learning and memory centre was established can not render subject useless in life. The problem of institutionalization which emanates from long stay, separates patients from socialization, work opportunities and recent life styles. This is worsened by stigmatization and prejudice of being a psychiatric and good for nothing. living, work and re-function in his choiced social environment--PRA (2015). Rehabilitation service 
is delivered so as to provide hope for hopeless patients. Here recovering clients obtain their lost regard of worthiness as he'll be taught to develop his wellness plans. From regular rehabilitation, his lost social network will be re-established while concerned relations will be permitted to visit him. Here activities like recreation, exchange of pleasantries, verbal interactions and discussions are permitted for exchange of ideas.

At the rehabilitation unit, patients are measured with Activity Therapy Evaluation (ATE) and Compulsive Occupational Therapy Evaluation Scale (COTE) for occupational diagnosis. E. Ikpeme (2015) explained that individualized treatment plan would be created for each patient after this assessment, giving room for prescribed activity best for each patient. Activities at psychiatric had progressed from era of entertainment, praise band and special numbers. Activities are now administered professionally by artisans to meet their dysfunctional areas.

\section{Statement of problems}

A whole lot of obscurity prevails over effectiveness of psychiatry rehabilitation in Calabar Psychiatry Hospital. Patients still goes on with idleness and laxity after several sessions with the therapist.

There is no sign of improvement in the learning facilities met since 2000 till now and most facilities are in dilapidated state. Ikpeme, E. (2015) expressed that the centre obtains no grant, subvention nor support from the hospital, State Government, Federal Government, or Non Governmental Organizations and Philanthropies. This supports the view from Babatunde, V. (2015), that there not enough facility in the centre, and the available facilities and service is below standard. This reveals that patient have been going on to relax in the hall till their time elapse while staff paid no heed to ensure learning and skill acquisition is impacted. Some staff might not surface on duty as they have no personal attachment to any of the patient.

When patients are granted trial leave, relatives only border on how to settle hospital bills. Patient's acquisition in rehabilitation therapy is not conveyed to the family for follow up and trade establishment. When patients fall back to recidivism and relapsed mental state the society will not trace blame to idleness but to any other precipitating factor.

Based on above facts it reveals that the rehabilitating service of Federal Psychiatric Hospital is useless. This prompts the researcher to investigate on the effectiveness of rehabilitation therapy on the in-mates of Calabar Psychiatric Hospital.

\section{Objectives of the study}

The purpose of this study is to assess the effectiveness of the ongoing rehabilitation program in Federal Psychiatric Hospital Calabar, its usefulness to patients and possible ways of improving the program. Specific objectives of the study are:

1. To determine the different types of rehabilitation therapy present in Federal Psychiatric Hospital, Calabar

2. To evaluate the patient's attitude towards the rehabilitation therapy

3. To determine the level of involvement of the patients family towards the rehabilitation programmes

4. To determine relationship between instructors qualification and effective implementation of the rehabilitation therapy

\section{Research questions}

1. What is the different rehabilitation therapies present in Federal Psychiatric Hospital, Calabar?

2. What is the attitude of patients toward the rehabilitation therapy? 
3. What is the level of involvement of patients' family towards the rehabilitation programmes?

4. What relationship exists between instructors' qualification and effective implementation of the rehabilitation therapy?

\section{Significant of the study}

Despite the preponderant view that psychiatry prognosis is ever un-productivity; it is not entirely true, and should not be allowed same. It's for the reason of disapproving that view that such program was introduced in psychiatry to rebuild lost abilities which were destroyed at the psychotic phase.

This study will direct on what to do about repairs, refurbishment, installation and replacement of aged machines and facilities to encourage patients the delight, desire and interest in our psychiatric rehabilitation; rather than feel there's nothing important going on there. Other unemployed youths finding where to belong in the society may be attracted down the centre to learn one trade or the order, yielding credit and interest to the hospital management.

The staff of our psychiatric rehabilitation would be more encouraged, retrained and empowered to be serious and put in their most for patients to be interested in their learning. The management at the hemp would have a footing to approach Federal and State Government, agencies and organizations on our rehabilitation refurbishment, in giving grants and supports to help the in-mates.

This solution will also provide outlet for further research study.

\section{Theoretical framework}

Theoretical framework of this study is community support theory; which links integration and community integration, psychosocial and rehabilitation theories.

Racino, J. (1999), supported the community support theory of involving total participation of every body in their community life; where disabled, psychiatric and the normal are important and should be merged together in formation of any great nation. Erickson in his psychosocial theory posited of the 8 essential stages of developments which every human undergoes, and along this cadre he learns new challenges involved in each stage. Clare Ovey (2013) stresses the need of reintegrating a convicted and unwanted fellow back to community in her rehabilitation theory. Hence every body is useful; society should not deride their citizen but help each other, and with love and peaceful co-existence one can learn from his errors and amend his ways for a fruitful relationship.

\section{Literature review}

Wikipedia-free encyclopedia regards psychiatry rehabilitation like psychosocial rehabilitation or psych rehab; as a program of restoring to community functioning and well-being of a person who was diagnosed as mental or emotionally sick with psychiatric disabilities. From antiquity when King Nebuchadnezzar became insane and was driven out from among men to the bush to eat herbs like beast-Daniel 4:32, the fulfilment of time came when his senses returned he was sought by his Counsellors and Lords who rehabilitated him and restored him back to his throneDaniel 4:36. Rehabilitation therapy commences after pharmacologic treatment and mental stability is established. It involves physical participation, independent living, skill training, psychological support of patient and family, vocational rehabilitation and employment--Psychosocial Rehabilitation Services (2015). Core principles of effective psychiatric rehabilitation (how services are delivered) must include: providing hope when the client lacks it, respect for the client wherever they are in the recovery process, empowering the client, teaching the client wellness planning, and 
South American Journal of Nursing

Special Edition

emphasizing the importance for the client to develop social support networks-PSR/RPS (2014).

Babatunde, Victor (2015) said that the available and accessible psychiatry rehabilitation involves indoor games, physical exercise and vocational activities like weaving, tailoring, barbing and craft work.

Anthony W. Cohen M. Farkas M, et al. (2002) confirmed that the goal of psychiatric rehabilitation is to help individuals with persistent and serious mental illness to develop the emotional, social and intellectual skills needed to live, learn and work in the community with the least amount of professional support

PSR/RPS (2014) further states the type of services delivered depends on provider's ability; and these includes: Psychiatric (symptom management; relaxation, meditation and massage; support groups and in-home assistance), Health and Medical (maintaining consistency of care; family physician and mental health counselling), Housing (safe environments; supported housing; community residential services; group homes; apartment living) and Basic Living Skills (personal hygiene or personal care, preparing and sharing meals, home and travel safety and skills, goal and life planning, chores and group decision making, shopping and appointments), Social (relationships, recreational and hobby, family and friends, housemates and boundaries, communications \& community integration), Vocational and/or Educational (vocational planning, transportation assistance to employment, preparation programs (e.g., calculators), GED classes, televised education, coping skills, motivation), Financial (personal budget), planning for own apartment (start up funds, security deposit), household grocery; social security disability; banking accounts (savings or travel), and Community and Legal (resources; health insurance, community recreation, memberships, legal aid society, homeownership agencies, community colleges, houses of worship, ethnic activities and clubs; employment presentations; hobby clubs; special interest stores; summer city schedules).

RCPsy. (2013), said rehabilitation is ability to restore to previous capacity, restore previous rights and prepares a subject to resume normalcy after mental illness, even to assume former status. People who are unable to cope with their daily activities or interact with others could do well to regain their independence and confidence through rehabilitation. It further revealed that rehabilitation team comprises Nurses, Psychologists, Psychiatrists, Occupational therapists and Social workers. Patients in need of rehabilitation are diagnosed schizophrenics, bipolar disorders and the schizoaffective. These have problems in organizing and planning their daily activities, hearing hallucination with communicative disabilities, they suffer people's condemnation, could not be easily understood by others, and were using alcohol with street drugs. Also recommended for rehabilitation are those with minimal medication effect in their system, and whose illness have hampered their concentration, interest and self coordination, clients with anxiety and depression, and those struggling to manage their daily activities.

\section{Delimitation of study}

The study is delimited to five variables: different type of rehabilitation on patients of Federal Psychiatric hospital, Calabar, attitude of patients toward rehabilitation therapy, level of involvement of patient's family towards the rehabilitation programmes, and instructors' qualification and effective implementation of rehabilitation therapy. It is also delimited to only the stable in-patients in Fedral Psychiatric Hospital, Calabar. 


\section{Limitation of the study}

The study was hindered by patient's unwillingness to co-operate, which was over come with thorough explanation of the relevance of the study to them.

\section{Research method}

This section is concerned with the method used for carrying out the study. It is organized under the following sub-headings: research design, area of the study, population of the study, sampling and sampling technique, research instrumentation, and validation of instrument, reliability of the instrument, research procedure and method of data analysis.

\section{Research design}

The ex-post facto research design was used for the study. This design was considered suitable for the study because the variables under investigation had presumably occurred and could not be experimentally manipulated in the process of the study.

\section{Area of study}

The study was conducted at Calabar, the capital city of Cross River State of Nigeria. The city is divided into two major local governments: Calabar Municipality and Calabar South Local Government Area. It served as the first Nigerian seat of government, blessed with Sea port, Airport, integrated stadium and an Export Free Zone where international commercial activity booms. Calabar is also blessed with Teaching Hospital, General Hospital, and Specialist Hospital, Health Centres and Primary Health Centres which takes care of healthcare delivery of the inhabitants.

\section{Population of study}

The population of study is the number of all in-mates of the hospital, which numbers 150 patients from ward 1 to $7-(\mathrm{OPC} / \mathrm{FPHC})$.

\section{Sampling and sampling technique}

The 50 stable patients used for this study were randomly picked from the four acute wards as they passed through the hospital rehabilitation centre for their rehabilitatiion learning.

\section{Research instrumentation}

An instrument titled "effectiveness of implementation of rehabilitation therapy for in-patients" was the instrument used for data collection. It consisted of 32 items expressed in check list and Likert format to measure the variables of the study.

\section{Validation of instrument}

The validity of the instrument was established using face validation method. This was done by giving copies of the instruments which initially consisted of 48 items to three experts to check if the items in the instrument appropriately measure the variables they were supposed to measure. Based on the observations, corrections and comments made by the experts, most of the items were either modified or deleted leaving only 32 items which made up the final version of the instrument. In this way, face validation was established for the instrument.

\section{Reliability of the instrument}

In order to establish reliability estimate for the instrument is was administered to 20 in-mates who were drawn from area of study were not to be included in the main study. The scores obtained were subjected to internal consistency methods using 
South American Journal of Nursing

Special Edition

Cronbach Alpha Analysis, a reliability estimate of 0.801 was obtained for the instrument.

\section{Administration of instrument}

The researcher personally visited these acute wards and obtained permission from their ward charges. He administered the instrument to the selected stable in-mates with the help of the duty Nursing Officer. The respondents were asked to be sincere in their responses as the data sought will be kept confidential and will only serve the purpose of this research.

\section{Method of data analysis}

Simple percentages will be used for answering research questions one, two and three while mean, standard deviation and r-value will be used for answering research question four. In taking decision, r-value between 0.1 to 0.39 is low; between 0.40 to 0.59 is average while between 0.60 to 0.99 is regarded as high relationship.

\section{Data analysis and results}

The results obtained are analysed in the light of the research questions formulated to guide the study

\section{Research question one}

What are the different rehabilitation therapies present in Federal Psychiatric Hospital, Calabar? Simple percentage was used to answer this research question. The result of the analysis is as presented in table 1.

Table 1. Responses of the patients on the types of rehabilitation programmes available in the hospital

\begin{tabular}{|l|l|l|l|l|l|}
\hline S/N & Rehabilitation Programmes & \multicolumn{2}{|l|}{ Available } & \multicolumn{2}{l|}{ Not available } \\
\hline & & Freq & $\mathbf{\%}$ & Freq & $\mathbf{\%}$ \\
\hline $\mathbf{1}$ & Moulding work & 50 & 100 & - & - \\
\hline $\mathbf{2}$ & Tailoring & 50 & 100 & - & - \\
\hline $\mathbf{3}$ & Designing & - & - & 50 & 100 \\
\hline $\mathbf{4}$ & Carpentry & - & - & 50 & 100 \\
\hline $\mathbf{5}$ & Laundering & - & - & 50 & 100 \\
\hline $\mathbf{6}$ & Knitting & 22 & 44 & 28 & 56 \\
\hline $\mathbf{7}$ & Catering & - & - & 50 & 100 \\
\hline $\mathbf{8}$ & Weaving & - & - & 50 & 100 \\
\hline $\mathbf{9}$ & Hairdressing/barbing & 41 & 82 & 9 & 18 \\
\hline $\mathbf{1 0}$ & Carpeting & - & - & 50 & 100 \\
\hline $\mathbf{1 1}$ & ICT & - & - & 50 & 100 \\
\hline $\mathbf{1 2}$ & Art Work & 50 & 100 & - & - \\
\hline
\end{tabular}

The result in the above Table 1 revealed that all the 50 respondents representing $100 \%$ indicated that moulding work, tailoring and artwork are available in the hospital. The result also revealed that 50 respondents representing $100 \%$ indicated that designing, carpentry; laundering, catering, weaving, carpeting and ICT programmes are not available in the hospital. The result further showed that 22 respondents representing $44 \%$ indicated that knitting is carried out by the patients in the hospitals while 28 respondents representing 56\% indicated other wise. And lastly, the result revealed that 41 respondents representing $82 \%$ indicated that hairdressing/barbing is available while 9 respondents representing 18\% indicated otherwise. This therefore implies that the types of rehabilitation programmes available for the patients of psychiatric hospital Calabar, Nigeria includes moulding work, tailoring and artwork, knitting and hairdressing/barbing. The implication of these findings is that there are only few rehabilitation programmes available for the 
patients; hence there is need for more programmes to be introduced so as to make varied skills available for the patients.

\section{Research question two}

What is the attitude of patients toward the rehabilitation therapy? Simple percentage was used to answer this research question. The result of the analysis is as presented in table 2 .

Table 2. Responses of the patients on the attitude of patients toward the rehabilitation therapy available

\begin{tabular}{|l|l|l|l|l|l|l|l|l|l|l|}
\hline S/N & $\begin{array}{l}\text { Attitude of } \\
\text { patients } \\
\text { towards the } \\
\text { programme }\end{array}$ & \multicolumn{2}{l|}{$\begin{array}{l}\text { Strongly } \\
\text { agree }\end{array}$} & \multicolumn{2}{l|}{ Agree } & \multicolumn{2}{l|}{ Disagree } & \multicolumn{2}{l}{$\begin{array}{l}\text { Strongly } \\
\text { disagree }\end{array}$} & Total \\
\hline 13 & $\begin{array}{l}\text { I have an } \\
\text { interest in the } \\
\text { hospital } \\
\text { rehabilitation } \\
\text { programmes }\end{array}$ & 45 & 90 & 5 & 10 & - & - & - & - & 50 \\
\hline 14 & $\begin{array}{l}\text { I am doing well } \\
\text { in my desired } \\
\text { rehabilitation } \\
\text { activity }\end{array}$ & 12 & 24 & 21 & 42 & 13 & 26 & 4 & 8 & 50 \\
\hline 15 & $\begin{array}{l}\text { I am always } \\
\text { excited during } \\
\text { training } \\
\text { sessions }\end{array}$ & 36 & 72 & 12 & 24 & 2 & 4 & - & - & 50 \\
\hline 16 & $\begin{array}{l}\text { I really enjoy } \\
\text { the programme }\end{array}$ & 32 & 64 & 15 & 30 & 2 & 4 & 1 & 2 & 50 \\
\hline 17 & $\begin{array}{l}\text { I will develop } \\
\text { on what I have } \\
\text { learnt at home }\end{array}$ & 28 & 56 & 10 & 20 & 5 & 10 & 7 & 14 & 50 \\
\hline
\end{tabular}

Table 2 shows that 45 respondents representing $90 \%$ of the respondents strongly agreed that they have interest in the hospital rehabilitation programmes while 5 respondents representing $10 \%$ agreed and none of the respondents disagreed or strongly disagreed. The table also shows that 12 respondents representing $24 \%$ of the respondents strongly agreed that they are doing well in their desired rehabilitation programmes, 21 respondents representing 42\% agreed whereas 13 respondents representing 26 disagreed and 4 respondents representing $8 \%$ strongly disagreed.

The table further revealed that 36 respondents representing $72 \%$ strongly agreed that they are always excited during training sessions, while 12 respondents representing 24\% agreed; only 2 respondents representing $4 \%$ disagreed and none strongly disagreed. The table also shows that 32 respondents representing $64 \%$ strongly agreed that they enjoy the programme, 15 respondents representing $30 \%$ agreed, 2 respondents representing 4\% disagreed and 1 respondent representing $2 \%$ strongly disagreed. And lastly, the table shows that 28 respondents representing 56\% strongly agreed that they will develop on what they have learnt, 10 respondents representing 20\% agreed while 5 respondents representing $10 \%$ disagreed and 7 respondents representing $14 \%$ strongly disagreed. This result implies that the patients have positive attitude towards the rehabilitation programmes. 
South American Journal of Nursing

Special Edition

\section{Research question three}

What is the level of involvement of patients' family towards the rehabilitation programmes? Simple percentage was used to answer this research question. The result of the analysis is as presented in table 3 .

Table 3. Responses of the patients on the level of involvement of patients' family toward the rehabilitation programmes

\begin{tabular}{|c|c|c|c|c|c|c|c|c|c|c|}
\hline \multirow[t]{2}{*}{$\mathrm{S} / \mathrm{N}$} & \multirow[t]{2}{*}{$\begin{array}{l}\text { Involvement } \\
\text { of patients } \\
\text { family }\end{array}$} & \multicolumn{2}{|c|}{$\begin{array}{l}\text { Strongly } \\
\text { agree }\end{array}$} & \multicolumn{2}{|c|}{ Agree } & \multicolumn{2}{|c|}{ Disagree } & \multicolumn{2}{|c|}{$\begin{array}{l}\text { Strongly } \\
\text { disagree }\end{array}$} & \multirow[t]{2}{*}{ Total } \\
\hline & & Freq & $\%$ & Freq & $\%$ & Freq & $\%$ & Freq & $\%$ & \\
\hline 18 & $\begin{array}{l}\text { My parents are } \\
\text { aware of the } \\
\text { hospital } \\
\text { rehabilitation } \\
\text { programmes }\end{array}$ & 50 & 100 & - & - & - & - & - & - & 50 \\
\hline 19 & $\begin{array}{l}\text { My parents } \\
\text { promise to } \\
\text { provide } \\
\text { required tools } \\
\text { and operating } \\
\text { shop for me } \\
\text { when I get } \\
\text { home }\end{array}$ & 8 & 16 & 14 & 28 & 25 & 50 & 3 & 6 & 50 \\
\hline 20 & $\begin{array}{l}\text { My relatives } \\
\text { advice me to } \\
\text { be attending } \\
\text { and partaking } \\
\text { in hospital } \\
\text { rehabilitation }\end{array}$ & 50 & 100 & - & - & - & - & - & - & 50 \\
\hline 21 & $\begin{array}{l}\text { My relatives } \\
\text { promise my } \\
\text { further } \\
\text { training }\end{array}$ & 10 & 20 & 15 & 30 & 22 & 44 & 3 & 6 & 50 \\
\hline 22 & $\begin{array}{l}\text { My relatives } \\
\text { appreciates } \\
\text { my progress in } \\
\text { the } \\
\text { programme }\end{array}$ & 17 & 34 & 18 & 36 & 5 & 10 & 10 & 20 & 50 \\
\hline
\end{tabular}

Table 3 shows that 50 respondents representing $100 \%$ of the respondents strongly agreed that their parents are aware of the hospital rehabilitation programmes. The table also revealed that 8 respondents representing $16 \%$ of the respondents strongly agreed that their parents promise to provide required tools and operating shop for them when they get home, while 14 respondents representing $28 \%$ agreed, 25 respondents representing 50\% disagreed and 3 respondents representing $6 \%$ strongly agreed. The table further showed that 50 respondents representing $100 \%$ of the respondents strongly agreed that their relatives advice them to be attending and partaking in the programme. The table also showed that 10 respondents representing $20 \%$ strongly agreed that their relatives promise them further training, 15 respondents representing 30\% agreed while 22 respondents representing $44 \%$ disagreed and 3 respondents representing 6\% strongly disagreed. And lastly, the table shows that 17 respondents representing 34\% strongly agreed that their relatives appreciates their 
progress in the programme, 18 respondents representing $36 \%$ agreed, while 5 respondents representing $10 \%$ disagreed and 10 respondents representing $20 \%$ strongly disagreed. This result implies that parent's level of involvement in the rehabilitation programme is low.

\section{Research question four}

What relationship exists between instructors' qualification and effective implementation of the rehabilitation therapy? Mean standard deviation and r-value of Pearson Product Moment Correlation was used to answer this research question. The result of the analysis is as presented in the table below:

Table 4. Mean, standard deviation and r-value of the relationship between instructors' qualification and effective implementation of the rehabilitation

\begin{tabular}{llll}
\hline Variables & Mean & Standard deviation & r-value \\
\hline Instructors' & 16.56 & 2.34 & 0.713 \\
qualification & 17.04 & 4.35 & \\
effective & & & \\
$\begin{array}{l}\text { implementation of } \\
\text { the rehabilitation } \\
\text { therapy }\end{array}$ & & & \\
\hline
\end{tabular}

The result in the table above revealed that the r-value of 0.713 is greater than 0.55 which is regarded as average relationship. This means that there is a relationship between instructors' qualification and effective implementation of the rehabilitation therapy.

\section{Summary of the results}

The findings of the study are summarised below:

1. There are few rehabilitation programmes available for the patients

2. The patients have positive attitude towards the rehabilitation programmes.

3. Parent's level of involvement in the rehabilitation programme is low.

4. There is a relationship between instructors' qualification and effective implementation of the rehabilitation therapy

\section{Discussion of findings}

The result of the first research question revealed that there are few rehabilitation programmes (moulding work, tailoring and artwork, knitting and hairdressing/barbing) that are available for patients in the hospital. The few rehabilitation programmes may be the reason why parent's involvement in the programme to be low. This is because the few programmes available may not appeal to parents as they may wish their patients to engage in other programmes other than the ones that are available.

Hence, rehabilitation programmes for the patients should be one that is able to provide every type of educational opportunity, experience or sound reasoning that may be of interest or benefit to their family member.

The result of the second research question revealed that the patients have positive attitude towards the rehabilitation programmes. This finding is possible because the patients are always looking for opportunities to leave the wards such that any such opportunity will keep them excited. Once again to make the programme more interesting to them, more programmes should be introduced so that it will meet the needs of the patients.

The result of the third research question revealed that parent's level of involvement in the rehabilitation programme is low. The reason that may give rise to this result could be that since the programmes available are few, the parents may not find them relevant and beneficial to their patients. The implication of this finding therefore, is 
South American Journal of Nursing

Special Edition

that efforts should be intensified towards diversifying the programmes and providing appropriate guidance to the patients in choosing courses that are related to them.

The result of the last research question revealed that there is a relationship between instructors' qualification and effective implementation of the rehabilitation therapy. The result is not surprising since almost all the instructors have undergone training in their areas of skills and as such they have the skills needed to facilitate their teaching.

\section{Conclusion}

Based on the findings of the study, it was concluded that rehabilitation programmes are effectively implemented in the Federal Psychiatric Hospital Calabar, Nigeria.

\section{Recommendations}

The following recommendations were made:

1. More rehabilitation programmes should be introduced into the hospital, this will help to meet the needs of the various patients

2. Social education and not just vocational education should be introduced as part of the rehabilitation programmes for patients. This social education should include courses in psychology and sociology for the readjustment of patient's thought.

3. The government through the media should create awareness to the parents on the importance of the rehabilitation programmes towards the recovery and functioning of the patients.

4. More qualified instructors and equipment should be made available to ensure effective implementation of the programme.

\section{Reference}

[1]. "About PRA". PRA - Psychiatric Rehabilitation Association. Retrieved 15 February 2015.

[2]. Anthony, W.A. (1979). The Principles of Psychiatric Rehabilitation. Baltimore, MD: Baltimore, MD: University Park Press.

[3]. Anthony, William A. (2009). "Editorial: Psychiatric rehabilitation leadership.". Psychiatric Rehabilitation Journal 33 (1): 7-8. doi:10.2975/33.1.2009.7. PMID19592372.

[4]. Anthony, William A.; Cohen, Mikal; Farkas, Marianne; Gagne, Cheryl (2002). Psychiatric Rehabilitation (2nd ed.). Boston, MA: Boston University, Center for Psychiatric Rehabilitation. ISBN 978-1-878512-11-6. OCLC 48958329.

[5]. Anthony, W.A. (1993, July). Psychosocial Rehabilitation Services, 17(1).

[6]. Anthony W. Cohen M. Farkas M, et al. Psychiatric rehabilitation. 2nd ed. Boston: Center for Psychiatric Rehabilitation, Boston University; 2002.

[7]. Carling, Paul J. (1995). Return to Community: Building Support Systems for People with Psychiatric Disabilities. New York: Guilford Press. ISBN 9780898622997. OCLC 30979396.

[8]. Carling, PJ (May 1993). "Housing and supports for persons with mental illness: Emerging approaches to research and practice". Hospital \& Community Psychiatry 44 (5): 439-449. PMID 8509074.

[9]. Cohen, M. R., Farkas, M.D., \& Cohen, B.F. (1986). Psychiatric Rehabilitation Training Technology: Functional Assessment. Boston: Boston University, Center for Psychiatric Rehabilitation.

[10]. Chamberlin, Judi (1978). On Our Own: Patient-controlled Alternatives to the Mental Health System. New York: Hawthorn Books. ISBN 9780801555237. OCLC 3688638.

[11]. Danley, K.S., Sciarappa, K., \& MacDonald-Wilson, K. (1992). Choose-get-keep: A psychiatric rehabilitation approach to supported employment. In: R.D. Liberman, New Directions in Mental Health Services: Effective Psychiatric Rehabilitation (Vol. 53, pp.87-96). San Francisco: Jossey-Bass.

[12]. Deegan, Patricia E. (January 1992). "The independent living movement and people with psychiatric disabilities: Taking back control of our lives". Psychosocial Rehabilitation Journal 15 (3): 3-19. doi:10.1037/h0095769 
[13]. Dion, G.L. \& Anthony, W.A. (1987). Research in psychiatric rehabilitation: A review of experimental and quasi-experimental studies. Rehabilitation Counseling, 30: 177-203.

[14]. Enabling recovery for people with complex mental health needs - a template for Rehabilitation service. Published by the Royal College of Psychiatrists' Faculty of Rehabilitation and Social Psychiatry, edited by Drs Paul Wolfson, Frank Holloway and Helen Killaspy.

[15]. Flexor, R.W. \& Solomon, P.L. (1993). Psychiatric Rehabilitation in Practice. Boston: Andover Medical.

[16]. Howie the Harp (May 1993). "Taking a new approach to independent living". Hospital \& Community Psychiatry 44 (5): 413. PMID 8509069.

[17]. Mowbray, C.T., Brown, K.S., Furlong-Norman, K. \& Soydan, A.S. (2002). Supported Education and Psychiatric Rehabilitation. Linthicum (Columbia), MD: International Association of Pyschosocial Rehabilitation Resources.

[18]. Murphy, S., Racino, J. \& Shoultz, B. (1991). "Rehabilitation of Persons with Psychiatric Disabilities: Course Curriculum." Syracuse, NY; Syracuse University, Division of Special Education and Rehabilitation.

[19]. Pratt, Carlos W.; Kenneth J. Gill, Nora M. Barrett and Melissa M. Roberts (2002). Psychiatric rehabilitation. San Diego: Academic Press. ISBN 978-0-12-564431-0. OCLC 64627515.

[20]. "Psychosocial Rehabilitation Association of Canada". PSR/RPS Canada.

[21]. "Psychosocial Rehabilitation Services". Mental Health: A Report of the Surgeon General. Washington, D.C.: United States Department of Health and Human Services. ISBN 978-0-16-0503009. OCLC 166315877.

[22]. Racino, Julie Ann (2000). Personnel Preparation in Disability and Community Life: Toward Universal Approaches to Support. Springfield, IL: Charles C. Thomas. ISBN 9780398070779. OCLC 43913226.

[23]. Racino, Julie Ann, ed. (2014). Public Administration and Disability: Community Services Administration in the US. Boca Raton: CRC Press. ISBN 9781466579811. OCLC 898155148.

[24]. Racino, 1999. Psychiatric survivors and the international self-help movement. In: J. A. Racino, Policy, Program Evaluation and Research in Disability: Community Support for All. London: The Haworth Press.

[25]. Racino, Julie Ann (May 1995), "Personal Assistance Services in the Field of Psychiatric Disabilities", Personal Assistance Services (PAS): Toward Universal Access to Support (Annotated Bibliography) (PDF), Washington, DC: National Institute on Disability and Rehabilitation Research (ED/OSERS), pp. 48-67 (PDF 53-72), ERIC ED405705

[26]. Raskin, Nathaniel J. (2004). Client-Centered Therapy and the Person-Centered Approach. Rosson-Wye, UK: PCCS Books. ISBN 9781898059578. OCLC 56955949.

[27]. Rudnick, Abraham; Roe, David, eds. (2011). Serious Mental Illness: Person-centered Approaches. London: Radcliffe. ISBN 9781846193064. OCLC 1846193060.

[28]. Salzer, Mark (2006). Psychiatric Rehabilitation Skills in Practice: A CPRP Preparation and Skills Workbook. Linthicum, Maryland: United States Psychiatric Rehabilitation Association. ISBN 978-0-9655843-6-4. OCLC 168391421.

[29]. Shoultz, Bonnie (1988). "My home, not theirs: Promising approaches in mental health and developmental disabilities". In Friedman, Steven J.; Terkelsen, Kenneth G. Issues in Community Mental Health: Housing. Canton, MA: Prodist (for Westchester County, NY Department of Community Mental Health). pp. 23-42. ISBN 9780881350531. OCLC 18625648.

[30]. "'Social inclusion and recovery"" (PDF). Australian Department of Health and Ageing.

[31]. Spaniol, LeRoy; Brown, Mary Alice; Blankertz, Laura; Burnham, Darrell J.; Dincin, Jerry; Furlong-Norman, Kathy; Nesbitt, Noel; Ottenstein, Paul; Prieve, Kathy; Rutman, Irvin; Zipple, Anthony, eds. (1994). An Introduction to Psychiatric Rehabilitation. Columbia, MD: International Association of Psychosocial Rehabilitation Services. OCLC 32406183.

[32]. Stewart, Loralee (1992). "PAS for People with Psychiatric Disabilities". In Weissman, Julie; Kennedy, Jae; Litvak, Simi. Personal Perspectives on Personal Assistance Services (PDF). Oakland, CA: World Institute on Disability. pp. 67-71 (PDF 75-79). 
South American Journal of Nursing

Special Edition

[33]. Stroul, Beth A. (January 1989). "Community support systems for persons with long-term mental illness: A conceptual framework". Psychosocial Rehabilitation Journal 12 (3): 9-26. doi: $10.1037 / \mathrm{h} 0099536$.

[34]. Unger, K.V. (1993, July). Creating supported education programs utilizing existing community resources. Psychosocial Rehabilitation Journal, 17(1): 11-23. 